\title{
仕上材を施した原コンクリートから製造した再生粗骨材 コンクリートの諸物性
}

一再生粗骨材コンクリートの圧縮強度, 静弾性係数および乾燥収縮—

\section{PHYSICAL PROPERTIES OF RECYCLED COARSE AGGREGATE CONCRETE MADE OF THE RAW CONCRETE WITH FINISHING MATERIALS}

-The compressive strength, static modulus of elastisity and drying shringkage of recycled coarse aggregate concrete-

柳㤵*，笠井芳夫**

Kei YANAGI and Yoshio KASAI

\begin{abstract}
This paper deals with the effects of sorts and contents of impurities in recycled coarse aggregate on the properties of recycled concrete. Recycled aggregate which was assumed producing from reinforced concrete structure of wall, floor and roof slub with several sorts of finishing materials. The sorts of finishing materials for original concrete were a multi-layer wall coating (ML), a synthetic resin emulsion paint (EP), a gypsum plaster (GP), a lime plaster (LP), a fibrous wall coating (FW), a ceramic tile (CT), a plastic tile (PT) and an asphalt membren water proofing (AM). The items of the investigations were on the compressive strength, static modulus of elastisity and drying shringkage of the recycled coarse aggregate concrete.
\end{abstract}

Key words; Finishing materials, Impurities, Recycled coarse aggregate concrete, Compressive strength, Static modulus of elastisity, Drying shringkage. 仕上材料、不純物、再生粗骨材コンクリート、圧縮強度、静弹性係数、乾燥收縮

1.はじめに

筆者等は、かねてより再生骨材に含まれる不純物が再 生コンクリートの諸性状に及ぼす影響について研究を進 めてきている。これまでの研究結果では、再生骨材の原 コンクリートの仕様が不明であること、コンクリート、 ブロック、A L C 等のいろいろなコンクリート塊が混合 していること等の理由によって不純物が再生骨材コンク リートに及ぼす影響を明らかにすることは出来なかった。

そこで、再生骨材に含まれる不純物はコンクリートに 施工された各種の仕上材によってもたらされると考え、 各種仕上材を施工した仕様の明確な原コンクリートから 再生粗骨材を製造し、再生粗骨材の品質およびこれを用 いた再生粗骨材コンクリートの諸物性について実験検討 を行った。なお、仕上材は壁用として複層仕上塗材 $(M L) 、$

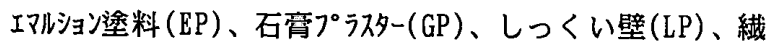
維壁(FW)およびセラミッ多仪(CT)を、床用としてプラスチッ多仪 （PT）を、また屋根用としてアスファルト防水層(AM)を施工した。 実験手順の概略を下記に示す。

* 建材試験センター中央試䀦所 専門職・修士 (工学)

** 日本大学生産工学部建築工学科 教授・博士 (工学)
（1） R C 構造物の壁、床、屋根を想定したコンクリー 卜板（寸法 $45 \times 90 \times 12 \mathrm{~cm}$; 壁估縦打ち、床、屋根结平打ち)をレテ イーミクストコンクリートを使用して打設。（材秢 1 週 間で脱型、その後仕上材施工まで屋外シート養生を実施) （2）コンクリート板の材齢 1 ヶ月の時、各種仕上材を 施工。（仕上材の技術者および技能士が施工）

（3）コンクリート板の材榷 2 ヶ月（仕上材施工後 1 ケ 月）の時、これを破砕・分級して再生粗骨材を製造。

(一次破砕 : 压砕機、2 次破砕 : ジョークラッシャー)

(4) 再生粗骨材コンクリートを調合し各種実験を実施。 前報 ${ }^{1}$ （再生粗骨材コンクリートの調合、凝結および ブリーティング) では再生粗骨材の製造（原コンクリ一 卜、仕上材の施エ、コンクリート板の破砕）、再生粗骨 材 (物理的性質、不純物量) 、再生粗骨材コンクリート の製造（使用材料、調合）再生粗骨材コンクリートのフ レッシュ性状（凝結およびブリーティング）について報 告した。ここでは、再生粗骨材コンクリートの圧縮強度、 静弾性係数および乾燥収縮について報告する。 Prof., College of Industrial Technology, Nihon Univ., Dr. Eng. 
2. 使用材料、再生数骨材コンクリートおよび供試体

(1) 使用材料

セメントは普通ポルトランドセメントを使用した。細 骨材は静岡県大井川産の川砂を、县骨材は東京都青梅市 産の硬質砂岩砕石（2005）を使用した。AE剂は天

\section{表・1コンクリートの基本調合}

\begin{tabular}{|c|c|c|c|c|c|c|c|}
\hline $\begin{array}{l}\text { בクリート } \\
\text { 引記号 }\end{array}$ & $\begin{array}{r}\text { 置換率 } \\
(\%)\end{array}$ & $\begin{array}{l}\text { スランプ } \\
(\mathrm{cm})\end{array}$ & $\begin{array}{l}W / C \\
(\%)\end{array}$ & $\begin{array}{l}S / a \\
(\%)\end{array}$ & $\begin{array}{c}\text { 単位水量 } \\
\left(\mathrm{kg} / \mathrm{m}^{3}\right)\end{array}$ & $\begin{array}{l}\text { 単值 } \\
(\mathrm{kg} / \mathrm{m}\end{array}$ & $\begin{array}{l}\text { 空気量 } \\
(\%)\end{array}$ \\
\hline NA & 0 & & & & & & \\
\hline$N F, R A$ & $30,50,100$ & $18 \pm 2.56$ & 60 & 44.0 & 181 & 302 & $4 \pm 1.5$ \\
\hline NAG, BRG & $1,3,5$ & & & & & & \\
\hline NAS, BRS & 1 & & & & & & \\
\hline & & -. & & . & & & \\
\hline NAS & 3 & & & 42.5 & 195 & 325 & \\
\hline NAS & 5 & $18 \pm 2.56$ & 60 & 41.0 & 205 & 342 & $4 \pm 1.5$ \\
\hline BRS & 3 & & & 41.5 & 201 & 335 & \\
\hline BRS & 5 & & & 40.5 & 208 & 347 & \\
\hline
\end{tabular}

注-1) 記号

NA ; 川砂・研石コンクリート。

NF100；川砂·再生粗骨材（确石に仕上材を含まない再生粗骨材を 100 置換)コンクリート。

$R A$; 川砂・砕石十再生粗骨材（碚石に再生粗骨材を $30,50,100 \%$ 置換) コンクリートの総称。再生粗骨材10種類,30調合。 RA30:砕石に再生粗骨材を30\%置換。(NF30,ML30,EP30等) RA50:砕石に再生粗骨材を $50 \%$ 置換。（LP50,FW50,CT50等） RA100:砕石に再生粗骨材を100\%置換。(PT100,AM100,BR100等)

NAG ; 川砂・砕石コンクリートで、ガラスを砕石に $(1,3,5 \%)$ 置換。 NAG1:ガラスを研石に1\%置換。 NAG3:ガラスを碎石に3\%罡換。 NAG5: ガラスを砕石に5\%置換。

BRG；川砂・混合再生粗骨材コンクリートで、ガラスを再生粗 骨材に $(1,3,5 \%)$ 置換。 BRG1: ガラスを再生冝骨材1\%に置換。 BRG3: ガラスを再生粗骨材3\%に置換。 BRG5:ガラスを再生粗骨材 $5 \%$ に置換。

NAS ; 川砂・砕石コンクリートで、土を碚石に $(1,3,5 \%)$ 置換。 NAS1:土を碎石に1\%置換。 NAS3:土を砕石に3\%置換。 NAS5:土を砕石に5\%置換。

BRS ; 川砂・混合再生粗骨材コンクリートで、土を再生粗骨材 に $(1,3,5 \%)$ 置換。

BRS1:土を再生粗骨材 $1 \%$ に置換。 BRS3:土を再生粗骨材 $3 \%$ に置換。 BRS5:土を再生粗骨材 $5 \%$ に置換。
然樹脂酸塩系の市販品を使用した。また、建築物の解体 時や再生粗骨材の製造過程での混入が考えられる不純物 としてガラス (G) および土 ( S ) を使用した。ガラス. (一般板ガラス) は2 $5 \sim 5 \mathrm{~mm}$ に粉砕したものを、ま た土 (関東ローム) は2 5〜5 m mのものを表乾状態に 近い状態に含水調整して使用した。

（2）コンクリート供試体の作り方

供試体は、JIS A 1115 (まだ固まらないコンクリート の試料採取方法) およびJIS A 1132 (コンクリートの強 度試験用供試体の作り方）に従って作製した。

\section{3. 実験項目および実験方法}

各種再生粗骨材を砕石に０、30、50およひ 100 \%置換した 31 種穎の再生粗骨材コンクリートと、砕石

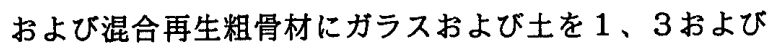
$5 \%$ 置換した 12 種類のコンクリートの合計 43 調合に ついて圧縮強度、静弾性係数および乾燥収縮試験を行っ た。コンクリートの基本調合を表・1 に示す。また実験 方法を表・2に示す。

\section{4. 実験結果および考察}

実験結果の一政を表・3および表・4に示す。考察に あたっては、主として仕上材を含まない再生粗骨材を全 量 (100\%) 使用した川砂・再生粗骨材コンクリート （記昂：N F 100 ）を基準とした。

\section{1 圧縮強度}

（1）仕上材の影響

表一 5 に各種再生粗骨材コンクリートの圧縮強度比を 仕上材を含まない再生粗骨材を $100 \%$ 置換した再生コ ンクリート（記号；NF100）の值を100として示 した。

(1) 標準水中養生 7 日の場合 : 砕石コンクリート（記号 ：NA）はNF100とほほ同じ值を示した。再生粗骨 材の置換率 $30 \%$ および $50 \%$ 再生コンクリート（記 号；RA３０およびRA５））は仕上材として織維壁を

表・ 2 実験方法

\begin{tabular}{|c|c|c|}
\hline 試験項目 & 規 & 善 生 方 法 \\
\hline 圧縮強度 & JIS A 1108(エンクリートの圧縮強度試駼方法) & 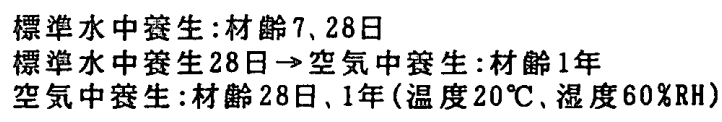 \\
\hline 静弾性䋆数 & JSTM C7103（エンクリー・0静弹性係数試験方法） & 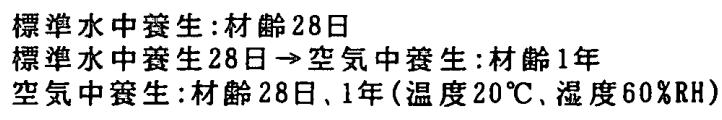 \\
\hline 乾燥収繀 & $\begin{array}{c}\text { JIS A } 1129 \text { (モルタル及Vエソクリート言長変化試験方法) } \\
\text { エンパレーター方法 }\end{array}$ & 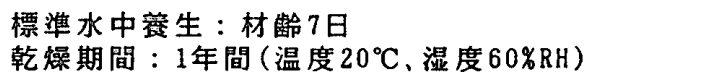 \\
\hline
\end{tabular}


表・3 圧縮強度、静弾性係数および乾燥収縮試験結果一覧（仕上材を含む再生粗骨材コンクリート）

\begin{tabular}{|c|c|c|c|c|c|c|c|c|c|c|c|c|c|c|}
\hline \multirow{2}{*}{$\begin{array}{l}\text { エンクリート } \\
\text { 記号 } \\
\\
\text { NA }\end{array}$} & \multirow{2}{*}{$\begin{array}{c}\text { 再生粗 } \\
\text { 骨材の } \\
\text { 置換率 } \\
(\%) \\
0\end{array}$} & \multicolumn{5}{|c|}{ 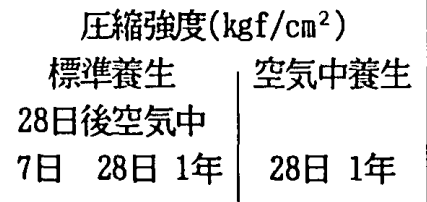 } & \multicolumn{4}{|c|}{$\begin{array}{l}\text { 静弾性係数 }\left(\times 10^{5} \mathrm{kgf} / \mathrm{cm}^{2}\right) \\
\text { 標準養生 } \\
\text { 28日後空気中 }\end{array}$} & \multicolumn{2}{|c|}{$\begin{array}{l}\text { 長䗀化(6ヶ月) } \\
\text { 乾燥 質量減 } \\
\text { 驱縮率 少率 } \\
\left(\times 10^{-4}\right)(\%)\end{array}$} & \multicolumn{2}{|c|}{$\begin{array}{l}\text { 長さ変化(1年) } \\
\text { 乾燥 質量減 } \\
\text { 収縮率 少率 } \\
\left(\times 10^{-4}\right)(\%)\end{array}$} \\
\hline & & 235 & 347 & 411 & 194 & 233 & 2.89 & 2.69 & 2.14 & 2.33 & 7.82 & 2.9 & 8.12 & 3.2 \\
\hline NF30 & 30 & 236 & 363 & 414 & 229 & 228 & 2.75 & 2.53 & 2.30 & 2.18 & 8.06 & 3.1 & 8.43 & 3.6 \\
\hline NF50 & 50 & 247 & 353 & 435 & 205 & 240 & 2.75 & 2.39 & 1.99 & 2.01 & 8.37 & 3.3 & 8.72 & 3.8 \\
\hline NF100 & 100 & 231 & 310 & 401 & 218 & 222 & 2.17 & 2.09 & 1.81 & 1.68 & 9.48 & 4.0 & 10.24 & 4.5 \\
\hline ML30 & 30 & 233 & 329 & 393 & 195 & 223 & 2.82 & 2.52 & 2.16 & 2.11 & 8.38 & 3.1 & 8.89 & 3.4 \\
\hline ML50 & 50 & 241 & 340 & 418 & 222 & 241 & 2.77 & 2.49 & 2.12 & 2.02 & 8.02 & 3.2 & 8.58 & 3.6 \\
\hline ML100 & 100 & 235 & 315 & 412 & 250 & 239 & 2.33 & 2.12 & 1.91 & 1.72 & 9.60 & 3.9 & 10.14 & 4.4 \\
\hline EP30 & 30 & 240 & 342 & 413 & 217 & 234 & 2.90 & 2.52 & 2.13 & 2.10 & 8.26 & 3.0 & 8.72 & 3.4 \\
\hline EP50 & 50 & 227 & 333 & 419 & 201 & 226 & 2.52 & 2.47 & 2.01 & 2.04 & 7.74 & 3.3 & 8.27 & 3.6 \\
\hline EP100 & 100 & 224 & 317 & 388 & 213 & 217 & 2.30 & 2.05 & 1.76 & 1.63 & 9.42 & 4.0 & 10.26 & 4.5 \\
\hline GP30 & 30 & 250 & 346 & 417 & 245 & 232 & 2.82 & 2.67 & 2.33 & 2.20 & 7.73 & 3.0 & 8.11 & 3.4 \\
\hline GP50 & 50 & 250 & 344 & 420 & 267 & 277 & 2.70 & 2.40 & 2.17 & 2.10 & 8.62 & 3.2 & 9.27 & 3.7 \\
\hline GP100 & 100 & 222 & 316 & 405 & 240 & 231 & 2.30 & 2.11 & 1.80 & 1.63 & 10.72 & 4.1 & 11.37 & 4.7 \\
\hline LP30 & 30 & 245 & 359 & 417 & 258 & 272 & 2.78 & 2.51 & 2.19 & 2.27 & 7.96 & 3.0 & 8.39 & 3.4 \\
\hline LP50 & 50 & 242 & 340 & 429 & 256 & 276 & 2.72 & 2.58 & 2.29 & 2.23 & 7.75 & 3.2 & 8.22 & 3.6 \\
\hline LP100 & 100 & 225 & 320 & 395 & 215 & 223 & 2.27 & 2.11 & 1.80 & 1.78 & 9.58 & 4.1 & 10.18 & 4.6 \\
\hline FW30 & 30 & 223 & 327 & 408 & 205 & 229 & 2.91 & 2.54 & 2.17 & 2.06 & 7.92 & 3.0 & 8.44 & 3.4 \\
\hline FW50 & 50 & 239 & 337 & 429 & 217 & 237 & 2.70 & 2.46 & 1.97 & 2.07 & 8.56 & 3.3 & 9.05 & 3.7 \\
\hline FW100 & 100 & 225 & 307 & 409 & 216 & 231 & 2.27 & 2.15 & 1.76 & 1.75 & 9.63 & 4.2 & 10.27 & 4.7 \\
\hline CT30 & 30 & 263 & 342 & 412 & 185 & 217 & 2.81 & 2.62 & 2.33 & 2.08 & 8.08 & 3.0 & 8.50 & 3.5 \\
\hline CT50 & 50 & 273 & 366 & 427 & 235 & 252 & 2.79 & 2.48 & 2.17 & 2.05 & 8.01 & 3.2 & 8.44 & 3.7 \\
\hline CT100 & 100 & 213 & 304 & 383 & 236 & 234 & 2.22 & 2.00 & 1.76 & 1.80 & 9.88 & 4.0 & 10.47 & 4.5 \\
\hline PT30 & 30 & 247 & 359 & 424 & 258 & 252 & 2.89 & 2.71 & 2.29 & 2.14 & 7.70 & 2.8 & 8.06 & 3.3 \\
\hline PT50 & 50 & 234 & 357 & 407 & 235 & 223 & 2.80 & 2.41 & 2.11 & 1.99 & 8.68 & 3.3 & 9.02 & 3.9 \\
\hline PT100 & 100 & 201 & 278 & 347 & 201 & 205 & 2.22 & 1.97 & 1.45 & 1.52 & 10.09 & 3.9 & 10.76 & 4.4 \\
\hline AM30 & 30 & 265 & 358 & 429 & 231 & 256 & 2.95 & 2.76 & 2.25 & 2.22 & 8.29 & 3.0 & 8.85 & 3.5 \\
\hline AM50 & 50 & 253 & 357 & 415 & 224 & 251 & 2.61 & 2.55 & 2.15 & 2.16 & 7.91 & 3.2 & 8.39 & 3.8 \\
\hline AM100 & 100 & 201 & 294 & 357 & 180 & 193 & 2.29 & 2.03 & 1.57 & 1.61 & 9.96 & 4.2 & 10.54 & 4.8 \\
\hline BR30 & 30 & 249 & 342 & 407 & 220 & 231 & 2.79 & 2.56 & 2.14 & 2.11 & 8.12 & 3.2 & 8.62 & 3.6 \\
\hline BR50 & 50 & 249 & 340 & 401 & 204 & 218 & 2.62 & 2.43 & 1.94 & 2.00 & 8.32 & 3.6 & 8.81 & 3.6 \\
\hline BR100 & 100 & 233 & 316 & 386 & 198 & 211 & 2.21 & 2.10 & 1.65 & 1.66 & 9.32 & 4.1 & 10.25 & 4.6 \\
\hline
\end{tabular}


表・4 圧縮強度、静弾性係数および乾燥収縮試験結果一㯺（ガラス、土を置換したコンクリート）

\begin{tabular}{|c|c|c|c|c|c|c|c|c|c|c|c|c|c|c|}
\hline \multirow{2}{*}{$\begin{array}{l}\text { エンクリート } \\
\text { 記号 } \\
\text { NAG1 }\end{array}$} & $\begin{array}{l}\text { がラス、 } \\
\text { 土の } \\
\text { 置換率 } \\
(\%)\end{array}$ & $\begin{array}{r}\text { 標 } \\
28 \text { 日 } \\
7 日\end{array}$ & $\begin{array}{l}\text { 圧縮 } \\
\text { 淮養生 } \\
\text { 後空今 } \\
\text { 28日 }\end{array}$ & $\begin{array}{l}\text { 郎 } \\
\text { E } \\
\text { 1年 }\end{array}$ & $\begin{array}{l}\mathrm{ff} / \mathrm{cm} \\
\text { 空気 } \\
28 \mathrm{E}\end{array}$ & 襄生 & \multicolumn{4}{|c|}{$\begin{array}{l}\left.\text { 静弾性係数 ( } \times 10^{5} \mathrm{kgf} / \mathrm{cm}^{2}\right) \\
\text { 標準善生 } \\
\text { 28日空気中養生 }\end{array}$} & \multicolumn{2}{|c|}{$\begin{array}{l}\text { 長祽化(6ヶ月) } \\
\text { 乾熳 質量減 } \\
\text { 収縮率 少率 } \\
\left(\times 10^{-4}\right)(\%)\end{array}$} & \multicolumn{2}{|c|}{$\begin{array}{l}\text { 長さ変化(1年) } \\
\text { 乾燥 質量減 } \\
\text { 収縮率 少率 } \\
\left(\times 10^{-4}\right)(\%)\end{array}$} \\
\hline & 1 & 232 & 335 & 382 & 236 & 247 & 2.90 & 2.79 & 2.16 & 2.41 & 7.14 & 2.9 & 7.74 & 3.3 \\
\hline NAG3 & 3 & 233 & 343 & 382 & 241 & 249 & 3.00 & 2.80 & 2.29 & 2.53 & 7.59 & 2.8 & 7.80 & 3.1 \\
\hline NAG5 & 5 & 236 & 328 & 371 & 205 & 211 & 2.92 & 2.63 & 2.25 & 2.42 & 7.38 & 3.1 & 7.84 & 3.5 \\
\hline BRG1 & 1 & 227 & 308 & 369 & 187 & 209 & 2.33 & 2.05 & 1.71 & 1.54 & 9.40 & 4.1 & 10.02 & 4.7 \\
\hline BRG3 & 3 & 201 & 289 & 339 & 209 & 212 & 2.16 & 1.99 & 1.59 & 1.59 & 10.26 & 4.4 & 10.76 & 4.9 \\
\hline BRG3 & 5 & 227 & 305 & 357 & 204 & 206 & 2.46 & 2.04 & 1.79 & 1.63 & 8.70 & 4.1 & 9.28 & 4.7 \\
\hline NAS1 & 1 & 261 & 368 & 395 & 208 & 237 & 2.90 & 2.61 & 2.16 & 2.15 & 8.54 & 3.0 & 9.07 & 3.3 \\
\hline NAS3 & 3 & 262 & 383 & 402 & 232 & 242 & 2.75 & 2.57 & 2.08 & 2.28 & 9.46 & 2.9 & 10.12 & 3.3 \\
\hline NAS5 & 5 & 258 & 379 & 396 & 238 & 220 & 2.71 & 2.30 & 1.91 & 1.98 & 9.67 & 3.2 & 10.34 & 3.6 \\
\hline BRS1 & 1 & 237 & 323 & 379 & 208 & 222 & 2.35 & 1.91 & 1.74 & 1.65 & 10.23 & 4.3 & 10.86 & 4.8 \\
\hline BRS3 & 3 & 244 & 333 & 357 & 249 & 230 & 2.15 & 1.85 & 1.84 & 1.63 & 10.45 & 4.4 & 11.24 & 5.1 \\
\hline BRS5 & 5 & 251 & 332 & 353 & 224 & 241 & 2.14 & 1.73 & 1.56 & 1.58 & 11.50 & 4.4 & 12.34 & 5.0 \\
\hline
\end{tabular}

含む再生粗骨材を砕石に対して $30 \%$ 置換した再生コン クリート（記号； FW 30) を除きNF100より大き い值を示した。仕上材を含む再生粗骨材を $100 \%$ 置換 した再生コンクリート（記号；ＲＡ１００）はプラスチ ックタイルを含む再生粗骨材を砕石に対して $100 \%$ 罳 換した再生コンクリート（記号；PＴ１００）およびア スファルト防水層を含む再生粗骨材を砕石に対し 100 \%置換した再生コンクリート（記号；A１１００）を除 いてNF100とほぼ同じ值を示した。P T 100 およ びAM 100 は F 100 に対しー $13 \%$ の值を示した。

(2) 標準水中養生 28 日および標準水中養生 28 日後空 気中養生 1 年の場合 : 標準水中養生材齢 28 日の場合、

RA 100 はN Aの $80 \sim 92 \%$ の值を示し、RA 30 およひRA 50 はいずれもN F 100 より大きくNAの 93 〜 $106 \%$ の值を示した。RA 100 の中で、P T 100 およびAM 100 はN F 100 に対し各々-10 \%およひー $5 \%$ の值を示し、圧縮強度の低下が大きい。

標準水中養生 28 日後空気中養生材齢 1 年の場合には RA 100 はN Aの 84 ～100\%の值を示し、標準水 中荃生 28 日の場合に比べ強度比が大きいが、これは再 生粗骨材コンクリートが砕石コンクリートよりも多くの 水分を含む事から乾燥環境における水和反忍が砕石コン クリートに比べて有利に進んだものと考えられる。 RA 30 およびR A 5 OはいずれもN F 100 より大き くかつNAの96〜 $104 \%$ の值を示した。RA 100 の中でP T 100 およひAM 100 はN F 100 に対し 各々ー $8 \%$ および- $13 \%$ の値を示し、仕上材としてプ
ラスチックタイルおよびアスファルト防水層が含まれる と材歯 28 日の場合と同様に圧縮強度の低下が大きい。

(3) 空気中養生 28 日および 1 年の場合 : 空気中荃生材 齢 28 日の場合、NAとNF100の圧縮強度は各々の 標準水中養生 28 日の $56 、 70 \%$ あり空気中荃生に おけるコンクリートの強度発現が不利であることを示し ている。また、NAに比べN F 100 の強度比が大きい のは、再生粗骨材コンクリートは粗骨材中により多くの 水分を含んでいることが原因と考えられる。RA 100 はNAの $93 \sim 129 \%$ RA 30 およびRA 5 Oは $85 \sim 118 \%$ を示し再生粗骨材コンクリートの種類、 置換率によって圧縮強度に及ぼす明確な傾向は認められ ない。

空気中堂生 1 年の場合、NAと N F 100 の圧縮強度 は各々の標準水中虽生 28 日後空気中養生 1 年の 57 、 $55 \%$ であり空気中養生が長期間に及ぶと強度比はほぼ 同程度となる。N Aの場合は材齢の進行に伴い約 $20 \%$ の強度増進がみられたのに対し、N F 100 の場合は、 わずか $2 \%$ の増進にとどまった。R Aの中で G P 50 、 L P 30 およびL P 50 は F 100 の圧縮強度の 20 \%以上の強度增進を示し、P T $100 、 \mathrm{~B} R 100$ お びAM 100 か各々 8 、 -9 およびー $17 \%$ を示した ことが特徵としてあげられる。GP 50 ，L P 3 Oおよ びL P 50 の圧縮強度が大きかった原因は再生粗骨材中 に含まれる石峦または石灰の反応等が考えられる。

(2) ガラスおよび土の影響

表・6にガラスおよび土を碎石および混合再生粗骨材 
表・5 コンクリートの圧縮強度比（\%）：仕上材を含む場合

\begin{tabular}{|c|c|c|c|c|c|c|c|c|c|c|c|c|c|c|c|}
\hline \multirow[t]{2}{*}{ 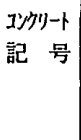 } & \multicolumn{3}{|c|}{ 標㾞水中羔生; 材齢7日 } & \multicolumn{3}{|c|}{ 標凖水中爰生;材能28日 } & \multicolumn{3}{|c|}{$\begin{array}{l}\text { 標準水中羙生 } 28 \text { 日後 } \\
\text { 空気中窊生;材橎1年 }\end{array}$} & \multicolumn{3}{|c|}{ 空気中䄜生;材龄28日 } & \multicolumn{3}{|c|}{ 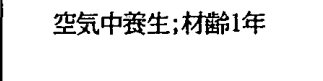 } \\
\hline & 30犆換 & 50\%监換 & 100\%置換 & 30\%置換 & 50\%置換 & 100\%岀檤換 & 30\%置換 & 50\%置換 & 100\%置換 & 30\%置換 & 50置換 & 100\%置換 & 30\%置換 & 50\%頤換 & 100\%置換 \\
\hline NF & 102 & 107 & 100 & 117 & 114 & 100 & 103 & 108 & 100 & 105 & 94 & 100 & 103 & 108 & 100 \\
\hline ML & 101 & 104 & 102 & 100 & 110 & 102 & 98 & 104 & 103 & 89 & 102 & 115 & 100 & 109 & 108 \\
\hline $\mathrm{EP}$ & 104 & 98 & 97 & 110 & 107 & 102 & 103 & 104 & 97 & 100 & 92 & 98 & 105 & 102 & 98 \\
\hline GP & 108 & 108 & 96 & 112 & 111 & 102 & 104 & 105 & 101 & 112 & 122 & 110 & 105 & 125 & 104 \\
\hline LP & 106 & 105 & 97 & 110 & 110 & 103 & 104 & 107 & 99 & 118 & 117 & 99 & 123 & 124 & 100 \\
\hline $\mathrm{FW}$ & 97 & 103 & 97 & 105 & 109 & 99 & 102 & 107 & 102 & 94 & 100 & 99 & 103 & 107 & 104 \\
\hline $\mathrm{CT}$ & 114 & 118 & 92 & 110 & 118 & 98 & 103 & 106 & 96 & 85 & 108 & 108 & 98 & 114 & 105 \\
\hline $\mathrm{PT}$ & 107 & 101 & 87 & 116 & 115 & 90 & 106 & 101 & 87 & 118 & 108 & 92 & 114 & 100 & 92 \\
\hline $\mathrm{AM}$ & 115 & 110 & 87 & 115 & 115 & 95 & 107 & 103 & 89 & 106 & 103 & 83 & 115 & 113 & 87 \\
\hline BR & 108 & 108 & 101 & 110 & 110 & 102 & 101 & 100 & 96 & 101 & 94 & 91 & 104 & 98 & 95 \\
\hline
\end{tabular}

注-2）同一空生におけるNF100の圧維強度の值を 100 とした值。

（仕上材の異なる 8 種類の再生粗骨材を等量混合した再 生粗骨材、記号；B R) に 1、3および 5 \%置換したコ ンクリートの压縮強度を N AおよびB R 100 と比較し て示した。

(1) 標準水中養生 7 日の場合 : 砕石にガラスを $1 、 3 お$ よび $5 \%$ 置換したNAG 1、NAG 3 および A G 5 の 圧縮強度はN Aとほとんど変わらないが、混合再生粗骨 材にガラスを置換したコンクリートの場合は B R 100

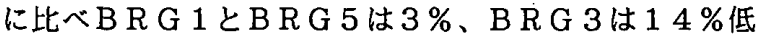
い值を示した。BR G 3 の圧縮強度が小さかった原因は コンクリート中の空気量が B R G 1 およびB R G 5 の場

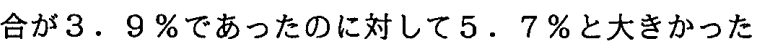
ことがあけられる。従って、砕石および混合再生粗骨材 にガラスを置換しても標準水中養生材歯 7 日のコンクリ 一トの圧縮強度には大きな影響を及ほさないものと考え られる。
砕石に土を $1 、 3$ および 5 \%置換した N A S は N Aの $110 \sim 111 \%$ 、また混合再生粗骨材に土を $1 、 3$ お よび $5 \%$ 置換したBR S B R $1000102 \sim 108$ \%であり土が混入したコンクリートの圧縮強度は、若干 大きくなる傾向を示した。

(2) 標準水中養生 28 日および標準水中養生 28 日後空 気中養生 1 年の場合 : 標準水中養生 28 日の場合、砕石 にガラスを置換したNAGはNAの $95 \sim 99 \%$ 、混合 再生粗骨材にガラスを置換した B R G はB R 100 に対 し 91 〜 7 \%を示し、ガラスを置換したNAGおよび B R G はガラスを置換しないN AおよびB R 100 に比 べ若干小さい值を示した。

碎石に土を置換したNAS はN Aの $106 〜 110 \%$ 、 また混合再生粗骨材に土を置換した B R S はB R 100 の $102 \sim 105 \%$ であり土が混入したコンクリート の標準水中養生材齢 28 日圧縮強度は土を置換しないコ ンクリートより若干大きくなる傾向を示した。

表・6 コンクリートの圧縮強度百分率（％）：ガラス（G）および土（ $\mathrm{S} ）$ を置換した場合

\begin{tabular}{|c|c|c|c|c|c|c|c|c|c|c|c|c|c|c|c|}
\hline \multirow[t]{2}{*}{$\begin{array}{l}\text { エソリート } \\
\text { 記 号 }\end{array}$} & \multicolumn{3}{|c|}{ 標準水中養生;材龄7日 } & \multicolumn{3}{|c|}{ 標準水中盖生;材歯28日 } & \multicolumn{3}{|c|}{$\begin{array}{l}\text { 標準水中養生 } 28 \text { 日後 } \\
\text { 空気中美生; 材噛1年 }\end{array}$} & \multicolumn{3}{|c|}{ 空気中坴生;材齢28日 } & \multicolumn{3}{|c|}{ 空気中養生;材齢1年 } \\
\hline & 1\%置換 & 3\%置換 & 5\%置換 & 1\%置換 & 3\%置換 & 5\%置換 & 1\%置換 & 1\%置換 & 5\%置換 & 1\%置換 & 3\%置換 & 5\%置換 & 1\%置換 & 3\%置換 & 5\%置換 \\
\hline NAG & 99 & 99 & 100 & 97 & 99 & 95 & 93 & 93 & 90 & 122 & 124 & 106 & 106 & 107 & 91 \\
\hline NAS & 111 & 111 & 110 & 106 & 110 & 109 & 96 & 98 & 96 & 107 & 120 & 123 & 102 & 104 & 94 \\
\hline BRG & 97 & 86 & 97 & 97 & 91 & 97 & 96 & 88 & 92 & 94 & 106 & 103 & 99 & 100 & 98 \\
\hline BRS & 102 & 105 & 108 & 102 & 105 & 105 & 98 & 92 & 91 & 105 & 126 & 113 & 105 & 109 & 114 \\
\hline
\end{tabular}

注-3）NAG、NAS；同一意生におけるNAの圧縮強度を100とした值。

BRG、BRS ; 同一養生におけるBR 100 の圧縮強度を 100 とした値。 
表・ 7 コンクリートの静弾性係数比（\%）：仕上材を含む場合

\begin{tabular}{|c|c|c|c|c|c|c|c|c|c|c|c|c|}
\hline \multirow[t]{2}{*}{$\begin{array}{l}\text { 訬行-1 } \\
\text { 記 号 }\end{array}$} & \multicolumn{3}{|c|}{ 摽準水中養生;材榷28日 } & \multicolumn{3}{|c|}{ 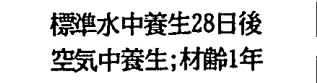 } & \multicolumn{3}{|c|}{ 空気中養生; 材新命28日 } & \multicolumn{3}{|c|}{ 空気中羪生;材踰1年 } \\
\hline & 30 笾換 & 50\%置換 & 100骂是換 & 30\%㟕換 & 50\%置換 & 100\%置換 & 30\%渍換 & 50\%造換 & 100尔通換 & 30\%西換 & 50㖵換 & $100 \%$ 迎換 \\
\hline NF & 127 & 127 & 100 & 121 & 114 & 100 & 127 & 110 & 100 & 130 & 120 & 100 \\
\hline ML & 130 & 128 & 107 & 121 & 119 & 101 & 119 & 117 & 106 & 126 & 120 & 102 \\
\hline EP & 134 & 116 & 106 & 121 & 118 & 98 & 118 & 111 & 97 & 125 & 121 & 97 \\
\hline GP & 130 & 124 & 106 & 128 & 115 & 101 & 129 & 120 & 99 & 131 & 125 & 97 \\
\hline LP & 128 & 125 & 105 & 120 & 123 & 101 & 121 & 127 & 99 & 135 & 133 & 106 \\
\hline FW & 134 & 124 & 105 & 122 & 118 & 103 & 120 & 109 & 97 & 123 & 123 & 104 \\
\hline $\mathrm{CT}$ & 129 & 129 & 102 & 125 & 119 & 96 & 129 & 120 & 97 & 124 & 122 & 107 \\
\hline $\mathrm{PT}$ & 133 & 129 & 102 & 130 & 115 & 94 & 127 & 117 & 80 & 127 & 118 & 90 \\
\hline $\mathrm{AM}$ & 135 & 120 & 106 & 132 & 122 & 97 & 124 & 119 & 87 & 132 & 129 & 96 \\
\hline$B R$ & 129 & 121 & 102 & 122 & 116 & 100 & 118 & 107 & 91 & 126 & 119 & 99 \\
\hline
\end{tabular}

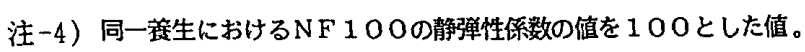

標染水中養生 28 日後空気中養生 1 年の場合、 $\mathrm{NA} \mathrm{G}$ はNAの $90 \sim 93 \%$ B R GはBR $100088 \sim$ $96 \%$ を示し、いずれもガラスを置換しないB R 100 に比べて若干小さい值を示した。また土を置換した場合、 NASはNAの $96 \sim 98 \%$ B R S B R $100 の$ $91 \sim 98 \%$ 示し、土が混入したコンクリートの 1 年 圧縮強度は、若干小さくなる傾向を示した。

(3) 空気中養生 28 日および 1 年の場合 : 空気中養生 28 日の場合、NAGはNAの106〜124\%を、ま たBRGはBR 100094 106\%を示したが、混 合再生粗骨材にガラスを置換したコンクリートは B R G 1

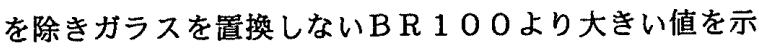
した。NASはNAの107〜123\%を、BRSは B R 100 O $105 \sim 126 \%$ 示し、土が混入したコ ンクリートの 28 日圧縮強度は若干大きくなる傾向を示 した。

空気中養生 1 年の場合、NAGはN Aの $91 \sim 107$ \%を、BR GはBR 100の98〜100\%を示したか、 いずれも置換率 $5 \%$ を除いて B R 100 より大きい值を 示した。またNASはNAの94〜104\%、BRSは B R 100の105〜114\%を示した。土が混入した 場合の空気中養生の材齢 1 年の圧縮強度はN A S 5 を除 き、若千大きくなる傾向を示した。

4.2 静弾性係数

(1) 仕上材の影響

表 -7 に各種再生粗骨材コンクリートの静弾性係数比 (仕上材を含まない再生粗骨材を $100 \%$ 政換したコン クリートの静弾性係数を 100 とした) を示した。

(1) 標準水中養生 28 日および標準水中養生 28 日後空
気中養生 1 年の場合 : 材路 28 日の場合、N Aの静弾性 係数は $2.89 \times 10^{5} \mathrm{~kg} \mathrm{f} / \mathrm{c} \mathrm{m}^{2}$ であった。仕上材 を含まない再生粗骨材を全量使用した再生コンクリート (記号；N F 100 ) の静弾性係数は $2.17 \times 10^{5}$ $\mathrm{kgf} / \mathrm{c} \mathrm{m}^{2}$ であり、NAの $75 \%$ の值であった。

N F 100 を基準にすると、RA 30 およびRA 5 0は $116 \sim 136 \%$ をし、RA100は102〜107 \%の值を示した。このことから仕上げ材を含んた再生粗 骨材を使用したR Aの材齢 28 日における静弾性係数は、 N F 100 の静弹性係数より大きいと言える。

標準水中養生 28 日後空気中養生 1 年の場合、N A 静弾性係数は $2.69 \times 10^{5} \mathrm{kgf} / \mathrm{c} \mathrm{m}^{2} 、 \mathrm{NF} 100$ は $2.09 \times 10^{5} \mathrm{kgf} / \mathrm{c} \mathrm{m}^{2}$ であり、標準水中養生 28 日の静弾性係数の各々 $93 \% 、 96 \%$ 值を示した。 これは乾燥によって静弾性係数が低下したものと考えら れる。また N F 100 を基準にすると、R A 30 およひ RA 50 は $115 \sim 132 \% 、 R A 100$ は4〜 103 \%であり、仕上材を含む再生粗骨材を $100 \%$ 使用した 再生粗骨材コンクリートの静弾性係数は材路の進行とと もに仕上材を含まない再生粗骨材コンクリートより小さ くなる傾向を示していると言える。

(2) 空気中養生 28 日およひ 1 年の場合 : 空気中養生の 材歯 28 日の場合、NAの静弾性係数は $2.14 \times 10^{5}$ $\mathrm{kgf} / \mathrm{c} \mathrm{m}^{2}$ を示し、またNF 100 は $1.81 \times 10^{5}$ $\mathrm{k} \mathbf{g} \mathbf{f} / \mathrm{c} \mathrm{m}^{2}$ を示した。これは、標準水中養生の場合の 各々 $74 \% 、 83 \%$ 值であり、乾燥環境におけるコン クリートの静弾性係数の増進は圧縮強度の場合と同様に 水中養生に比べて不利であると言える。N F 100 を基 準にすると、RA３０およひRA 50 は $107 \sim 129$ 
表・8 コンクリートの静弾性係数比（％）：ガラス（G）および土（S）を置換した場合

\begin{tabular}{|c|c|c|c|c|c|c|c|c|c|c|c|c|}
\hline \multirow[t]{2}{*}{$\begin{array}{l}\text { エタクート } \\
\text { 記 号 }\end{array}$} & \multicolumn{3}{|c|}{ 標準水中養生;材齢28日 } & \multicolumn{3}{|c|}{$\begin{array}{l}\text { 標淮水中羔生28日後 } \\
\text { 空気中苝生;材敬令1年 }\end{array}$} & \multicolumn{3}{|c|}{ 空気中養生;材齢28日 } & \multicolumn{3}{|c|}{ 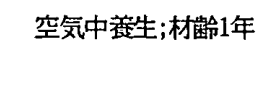 } \\
\hline & 1\%置換 & 3\%置換 & 5\%置換 & 1\%置換 & 3\%置換 & 5\%置換 & 1\%置換 & 3\%置換 & 5\%置換 & 1\%置換 & 3\%置換 & 5\%置換 \\
\hline NAG & 100 & 104 & 101 & 104 & 104 & 98 & 101 & 107 & 105 & 103 & 109 & 104 \\
\hline NAS & 100 & 95 & 94 & 97 & 96 & 86 & 101 & 97 & 89 & 92 & 98 & 85 \\
\hline B RG & 105 & 98 & 111 & 98 & 95 & 97 & 104 & 96 & 108 & 93 & 96 & 98 \\
\hline BRS & 100 & 97 & 97 & 91 & 88 & 82 & 105 & 112 & 95 & 99 & 98 & 95 \\
\hline
\end{tabular}

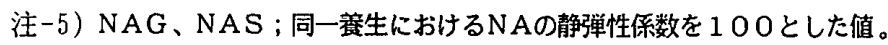
BRG、BRS ; 同一羔生におけるBR 100 静弾性係数を 100 とした値。

\%を示し、RA 100 は $80 \sim 106 \%$ 值を示した。 R A 100 の中ではP T 100 か $80 \%$ AM 100 が $87 \%$ おびBR 100 が91\%を示したことが特徵的 である。

空気中養生 1 年の場合、NAの静弾性係数は 2.33 $\times 1 \mathrm{O}^{5} \mathrm{~kg} \mathrm{f} / \mathrm{c} \mathrm{m}^{2} 、 \mathrm{NF} 100$ は $1.68 \times 10^{5}$ $\mathrm{kg} \mathrm{f} / \mathrm{c} \mathrm{m}^{2}$ であり、標準水中養生 28 日後空気中養 生 1 年の場合の各々 $87 \% 、 80 \%$ 值を示した。 N F 100 を基準にすると、R A 30 およびR A 5 Oは $114 \sim 135 \%$ を RA 100 は 9 O $107 \%$ を示

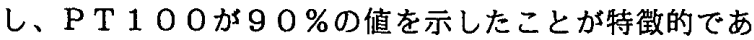
る。

\section{(2) ガラスおよび土の影㸷}

表・ 8 に材秢 28 日および 1 年の静弾性係数をN Aお よびBR 100 と比較して示した。

(1) 標準水中養生 28 日および標準水中養生 28 日後空 気中養生 1 年の場合: 標準水中養生 28 日の場合、砕石 にガラスを置換したNAGはNAの100〜104\%、 混合再生粗骨材にガラスを置換した B R G は B R 100 の98〜111\%であり、ガラスを置換したNAGおよ びB R GはいずれもNA およびB R 100 に比べてほぼ 等しいかまたは若干大きい值を示した。研石に土を置換 したNASは NAの94〜100\%、また混合再生粗 骨材に土を置換したB R S はB R 100 の 7 〜 100 \%であり土が混入した場合には、静弾性係数が若干小さ くなる傾向を示した。

標準水中養生 28 日後空気中養生 1 年の場合、 $\mathrm{NAG}$ はNAの9 8〜104\%を、BRGはBR 100095 〜 $98 \%$ 示し、いずれもガラスを置換しない場合と大 差ない值を示した。また土を置換した場合にはNA S は NAの $86 \sim 97 \%$ 、またB R S B R 100082 〜 $91 \%$ を示し、土が混入したコンクリートの静弾性係 数は、土の置換率に比例して小さくなる傾向を示した。

(2) 空気中養生 28 日および 1 年の場合 : 空気中養生 28 日の場合、N A Gの静弾性係数はN Aの 101 ～
$107 \%$ 示し、BR GはBR 100096 108\% を示した。NASはNAの89〜101\%を、BR S は B R 100 0 5〜 $112 \%$ を示し、土が混入すると砕 石コンクリートの場合は置換率に比例して静弾性係数は 低下する傾向を示すが、混合再生粗骨材コンクリートの 場合は置換率 $3 \%$ で最大值を示しN A S と異なる傾向を 示した。

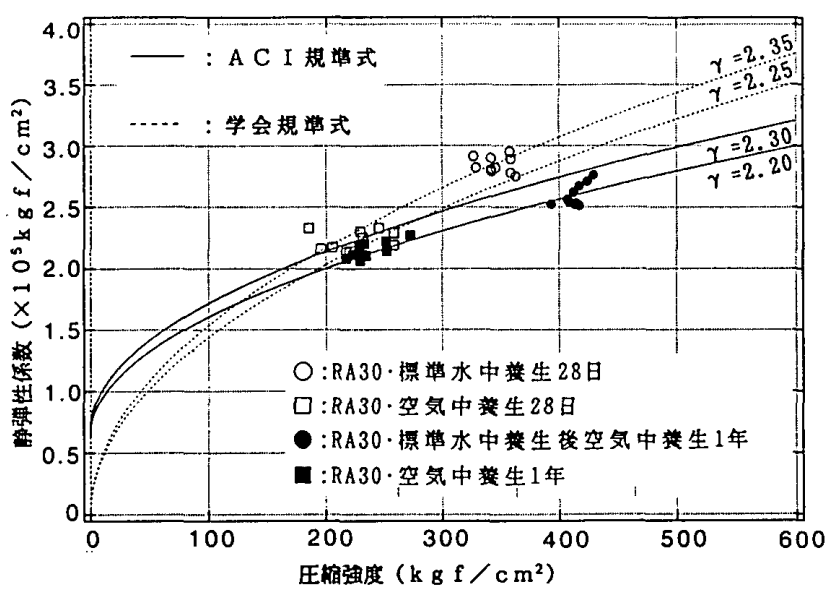

図・1 圧縮強度と静弾性係数との関係 (仕上材；置換率 $30 \%$ )

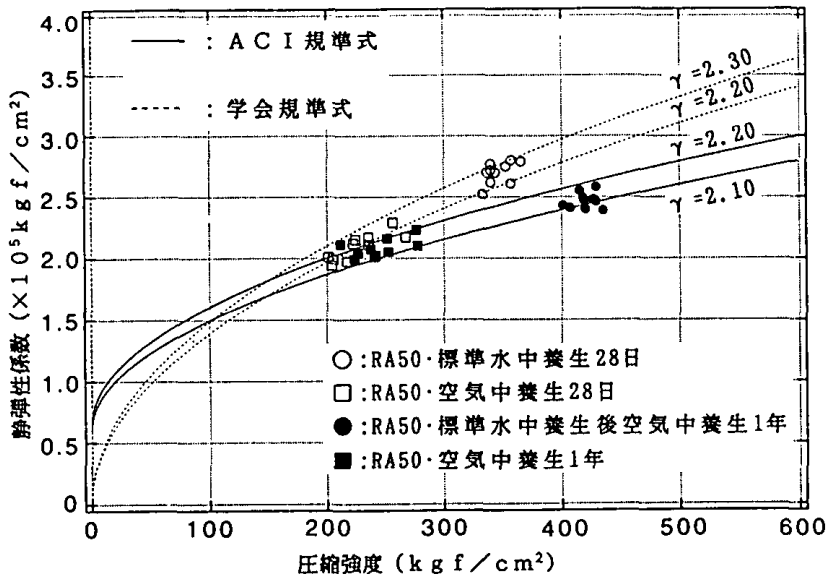

図・2 圧縮強度と静弾性係数との関係 （仕上材；置換率 $50 \%$ ） 
空気中竞生 1 年の場合、NAGの静弾性係数はN Aの $103 \sim 109 \%$ を、BRGはBRの $85 \sim 98 \%$ を示 し、䂶石にガラスが混入すると静弾性係数は若干大きく なるが混合再生粗骨材に混入すると小さくなる傾向を示 した。また、NASはNAの85〜98\%を、BR Sは B R $100095 \sim 99 \%$ を示し、が混入すると、そ の置換率に比例して静弾性係数は低下する傾向を示した。 （３）圧縮強度と静弹性係数の関係

圧縮強度と静弾性係数の関係を再生粗骨材の置換率別 およびガラス、土の置換別に日本建築学会「鉄筋コンク リート構造計算規準」の(1)式（以後、学会規準式と言 う)およびACI B u i l ding Codeに示さ れた(2)式（以後、A C I 規準式と言う）と比較して図・ 1 〜図・5に示した。

$$
\begin{aligned}
& \mathrm{E}=2.1 \times 10^{5} \times(\gamma / 2.3)^{1.5} \times(\mathrm{Fc} / 200)^{0.5} \\
& \mathrm{E}=(10600 \sqrt{\mathrm{Fc}}+70300) \times(\gamma / 2.346)^{1.5} \\
& こ こ に 、 \mathrm{E}: \text { 静弾性係数 }\left(\times 10^{5} \mathrm{kgf} / \mathrm{cm}^{2}\right)
\end{aligned}
$$

$$
\text { Fc : コンクリートの圧縮強度 }\left(\mathrm{kgf} / \mathrm{cm}^{2}\right)
$$

$\gamma:$ コンクリートの気乾単位容積質量 $\left(\mathrm{t} / \mathrm{m}^{3}\right)$

(1) 置換率 $30 \%$ の場合（図・1）; 標準水中養生 28 日および空気中養生 28 日の静弾性係数は、学会規準式 の $\gamma=2.25 \sim 2.35$ (試験時供試体の $\gamma ; 2.20$ ２，33）に、標準水中養生 28 日後空気中養生 1 年 および空気中養生 1 年の静弾性係数は、A C I 規準式の $\gamma=2.20 \sim 2$. 30 (試験時供試体の $\gamma ; 2.18$ 〜 2. 24 ) にほほ一致する。

(2) 置換率 $50 \%$ の場合（図・2）; 標準水中養生 28 日およひ空気中養生 28 日の静弾性係数は学会規準式の $\gamma=2.20 \sim 2.30$ （試験時供試体の $\gamma ; 2.16$ ～2.31) に、また標準水中養生 28 日後空気中養生 1 年および空気中養生 1 年の静弾性係数は A C I 規準式 の $\gamma=2.10 \sim 2.20$ (試験時供試体の $\gamma ; 2.15$ 〜2.23)にほほ一致する。

（3) 置換率 $100 \%$ 場合（図·3）;標準水中養生 28 日および空気中養生 28 日の静弾性係数は学会規準式 の $\gamma=2$. $00 \sim 2.10$ (試験時供試体の $\gamma ; 2.07$ $\sim 2.24$ ) に、標準水中養生 28 日後空気中養生 1 年 および空気中養生 1 年の静弾性係数はA C I 規準式の $\gamma$ $=1.90$ (試験時供試体の $\gamma ; 2.05 \sim 2.14$ ) に概ね回帰するか、、圧縮強度の值から静弾性係数を推定 しようする場合には学会規準式およびAＣＩ規準式に試 験時供試体の $\boldsymbol{\gamma}$ をそのまま使用すると試験によって得ら れる静弾性係数の值より大きくなる危険性がある。

(4) ガラス置換の場合 ; 図・4に示したように、標準 水中荃生 28 日および空気中養生 28 日の静弾性䋆数は 学会規算式の $\gamma=2.10 \sim 2.40$ （試験時供試体の $\gamma ; 2.10 \sim 2.30)$ にまた、標準水中養生 28 日 後空気中養生 1 年および空気中養生 1 年の静弾性係数は

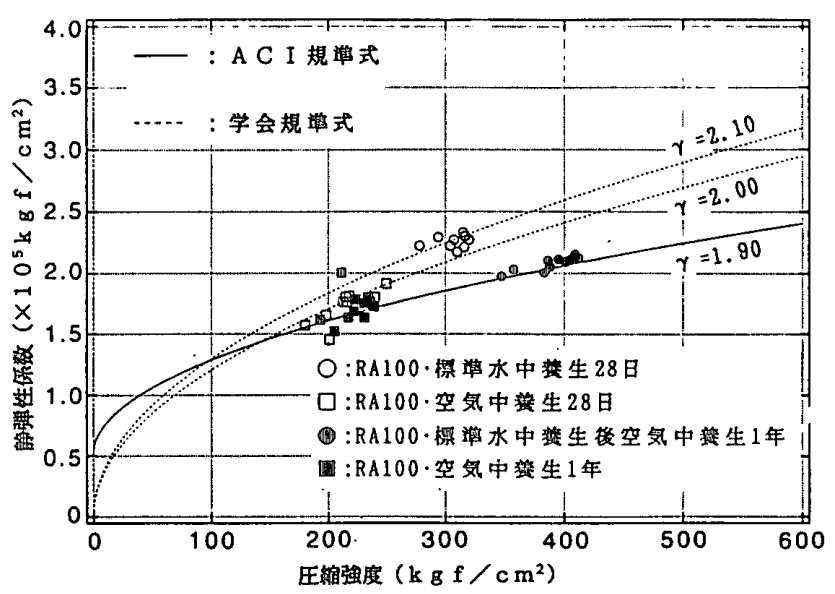

図・3 圧縮強度と静弾性係数との関係 (仕上材；置換率 $100 \%$ )

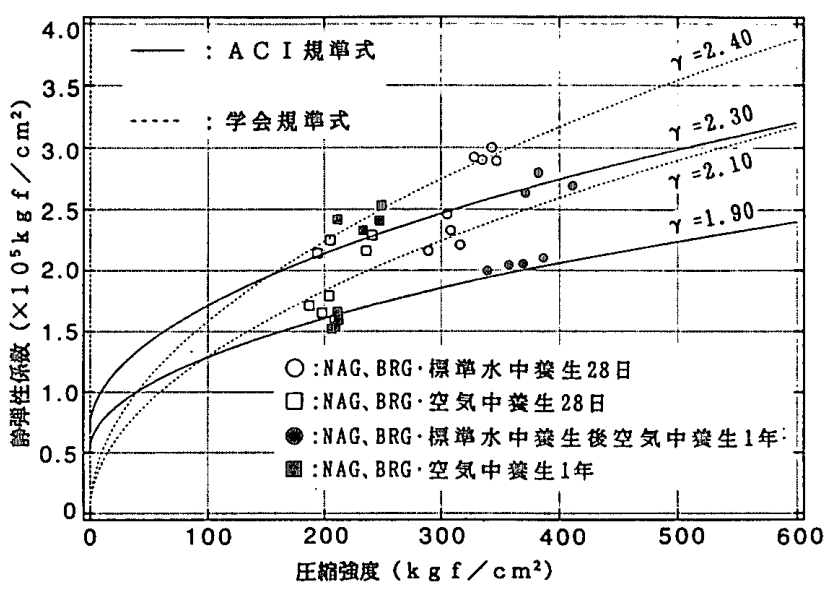

図・4 圧縮強度と静弾性係数との関係 (ガラス置換率 $1 、 3$ および $5 \%$ )

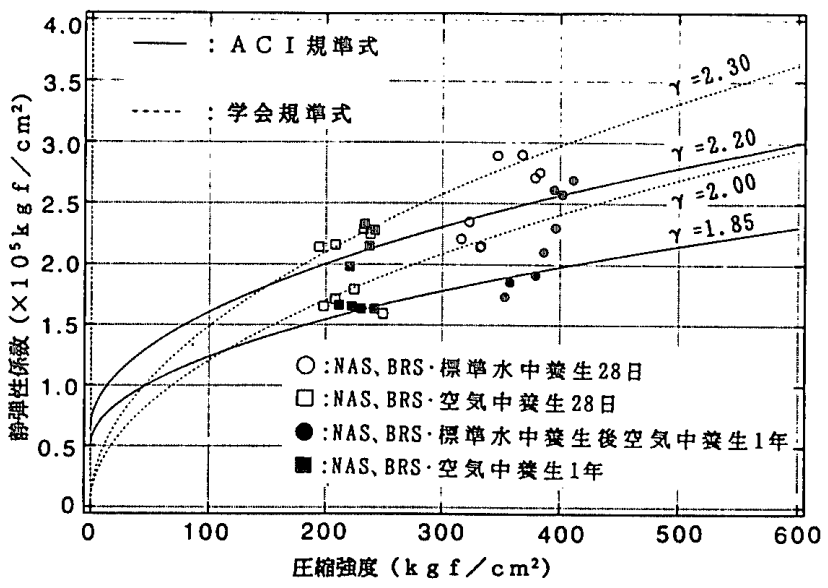

図・5 圧縮強度と静弾性係数との関係 （土置換率 1、3および $5 \%$ ）

A C I 規準式の $\gamma=1.90 \sim 2.30$ (試験時供試体 の $\gamma ; 2.10 \sim 2.31$ ) に概标回帰する。しかしな がら、材齢 1 年における静弾性係数をAＣＩ規準式から 推定する場合には $\gamma$ の值の補正が必要である。 
(5) 土置換の場合、困・5 に示したように、標準水中 養生28日および空気中養生 28 日の静弾性係数は学会 規準式の $\gamma=2.00 \sim 2.30$ (試験時供試体の $\gamma$; 2. $06 \sim 2.32$ ) にまた標準水中養生 28 日後空気 中養生 1 年および空気中養生 1 年の静弹性係数はA C I 規準式の $\gamma=1.85 \sim 2.20$ (試験時供試体の $\gamma$; 2. $06 \sim 2.22$ ) に概极回㷌する。

以上述べたように、再生粗骨材コンクリートの静弾性 係数は、養生条件等が異なる等の問題はあるものの概略 材齢 28 日の場合は学会規準式が、また材齢 1 年の場合 はA C I 規準式が適用出来そうである。再生粗骨材の置 換率 $30 \%$ 及び $50 \%$ の再生粗骨材コンクリートの場合

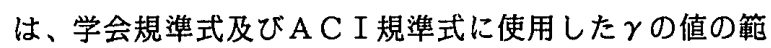
囲と試験時供試体の $\gamma$ の值の範囲とがほぼ一致する。従 って学会規準式又はAＣＩ規準式を使用して、圧縮強度 と供試体の $\gamma$ の值から静弹性性係数を推定する事が可能 である。しかしながら、置換率 $100 \%$ の場合および土 を置換した場合には、学会規準式及びAＣＩ規準式に用 いた $\gamma$ の值が実際の供試体の $\gamma$ の值より小さい。そのた めに学会規準式及び A C I 規準式に供試体の $\gamma$ をそのま ま適用すると実験により得られる静弾性係数の値より大 きくなる危険性がある。

\section{3 乾燥収縮}

(1) 仕上材の種類と乾燥収縮: 表- 9 に各種再生粗骨材 コンクリートの乾燥収縮率の比を仕上材を含まない再生

表・9 コンクリートの乾燥収縮率の比（\%）： 仕上材を含む場合

\begin{tabular}{|c|c|c|c|c|c|c|}
\hline \multirow{2}{*}{$\begin{array}{l}\text { Iy夕y-r } \\
\text { 記 号 }\end{array}$} & \multicolumn{3}{|c|}{ 乾燥期間 6 ヶ月 } & \multicolumn{3}{|c|}{ 乾燥期間 1 年 } \\
\hline & 30\%犆換 & 50\%置換 & 100\%置換 & 30\%置換 & 50\%置換 & 100\%置換 \\
\hline NF & 85 & 88 & 100 & 82 & 85 & 100 \\
\hline$M L$ & 88 & 85 & 101 & 87 & 84 & 99 \\
\hline EP & 87 & 82 & 99 & 85 & 81 & 100 \\
\hline GP & 81 & 91 & 113 & 79 & 91 & 111 \\
\hline L P & 84 & 82 & 101 & 82 & 80 & 99 \\
\hline FW & 84 & 90 & 102 & 82 & 88 & 100 \\
\hline $\mathrm{CT}$ & 85 & 84 & 104 & 83 & 82 & 102 \\
\hline $\mathrm{PT}$ & 81 & 92 & 106 & 79 & 88 & 105 \\
\hline $\mathrm{AM}$ & 87 & 83 & 105 & 86 & 82 & 103 \\
\hline BR & 86 & 88 & 98 & 84 & 86 & 100 \\
\hline
\end{tabular}

注-6）同一乾燥期間におけるNF100の乾燥収縮率 を100とした值。
粗骨材を $100 \%$ 置換した再生コンクリートの乾燥収縮 率を 100 として示した。乾燥期間 1 年におけるのN F 100 の乾燥收縮率は $10.24 \times 10^{-4}$ であり、研石 コンクリート（N A； $\left.8.12 \times 10^{-4}\right)$ のそれに比べ $21 \%$ 大きい。この值は（社）建築業協会の報告にほほ 等しい。3)置換率 $30 \%$ における再生粗骨材コンクリー トの乾燥収縮率の比はN F 100 に対して $81 \sim 88 \%$ (平均 $85 \%$ ) である。置換率 $50 \%$ では $82 \sim 92 \%$ （平均 $86 \%$ ）の範囲にあり、仕上材からもたらされた 不純物を含む再生粗骨材コンクリートの乾燥収縮率は置 換率 30 および $50 \%$ の場合には不純物を含まない再生 粗骨材コンクリートより小さい值を示した。また置換率 $100 \%$ ば $96 \sim 114 \%$ (平均 $102 \%$ ）であり、 仕上材からもたらされた不純物が乾㷥収縮に影響するも のと影響しないものがある。影響の大きいものとしては GP $100(114 \%)$ およびP T $100(110 \%)$ があげられる。乾燥に伴う質量減少率も収縮率の場合と 同様に置換率の増加に伴い大きくなった。

(2) ガラスおよび土の影響: 表・10にガラスおよび土 を置換したコンクリートの乾爆収縮象の比を示した。こ れによると、砕石および再生粗骨材にガラス及び土を置 換するとガラスの場合には置換しないコンクリートの乾 燥収縮率とほとんど変わらないが、土の場合にはN A S がNAの 112 127\%、BR Sが $106 \sim 120 \%$ を示し、土の置換によって乾燥収縮率が大きくなった。

(3) コンクリート中の全水量（単位水量と骨材の吸水率 相当分の水量の和）と乾燥收縮率との関係を図・6に示 す。ガラスを置換したコンクリートの乾燥収縮率は、砕 石コンクリートおよび混合再生粗骨材コンクリートと変 わらないが、土を置換したコンクリートの乾燥収縮率は 大きくなる事がわかる。また、乾燥期間 6 ケ月を基準と してその前後の収縮率の変化を碎石コンクリートと比べ ると、再生粗骨材コンクリートは何れの場合も大きい。

表・10 コンクリートの乾燥収縮率の比（％）：

カララス（G）および土（S）を置換した場合

\begin{tabular}{|c|c|c|c|c|c|c|}
\hline \multirow{2}{*}{$\begin{array}{l}\text { x夘抄- } \\
\text { 記 号 }\end{array}$} & \multicolumn{3}{|c|}{ 乾燥期間 6 ヶ月 } & \multicolumn{3}{|c|}{ 乾燥期間 1 年 } \\
\hline & $1 \%$ & $3 \%$ & $5 \%$ & $1 \%$ & $3 \%$ & $5 \%$ \\
\hline NAG & 91 & 97 & 94 & 95 & 96 & 97 \\
\hline NAS & 109 & 121 & 124 & 112 & 125 & 127 \\
\hline$B R G$ & 101 & 110 & 93 & 98 & 105 & 91 \\
\hline BRS & 110 & 112 & 123 & 106 & 110 & 120 \\
\hline
\end{tabular}

注-7）NAG、NAS；NAの乾燥收縮率を100とした值。 BRG、BRS；BR100の乾燥収縮率を100とした值。 


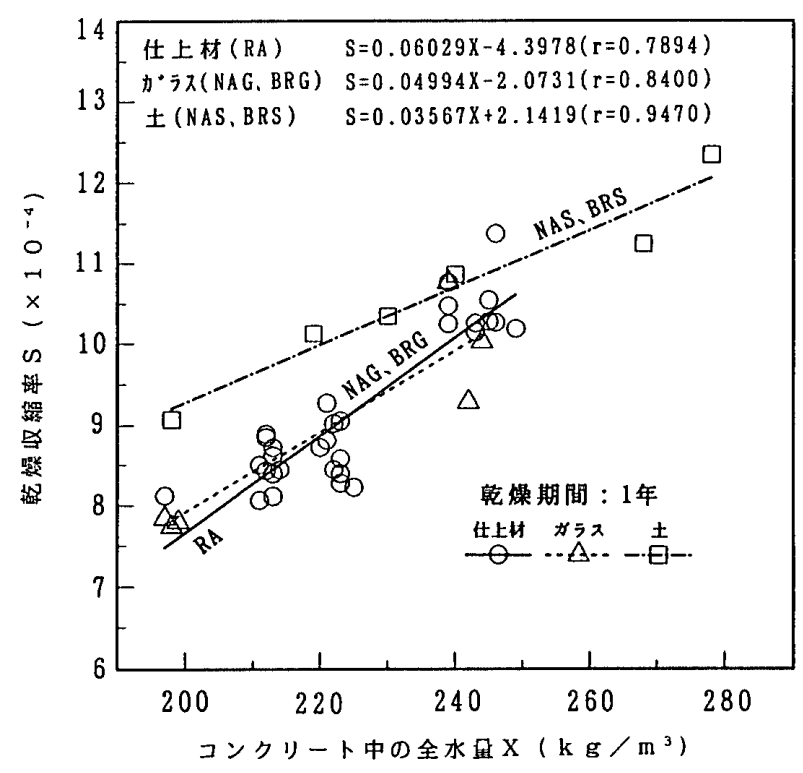

図・6 コンクリート中の全水量と乾燥収縮率との関係

そこで、通常の乾焻収縮試験は乾燥期間を 3 ケ間また は6ヶ月間としてその結果を評価する場合が多いが、再 生粗骨材コンクリートの場合には収縮率が一定になるま で時間を要するため乾爆期間 1 年間程度の湘定結果で評 価することが必要である。

\section{5 .まとめ}

各種仕上材を施したコンクリートを破砕して再生粗骨 材を製造し、これを用いた再生粗骨材コンクリートの圧 縮強度、静弾性係数および乾燥収縮について実験研究を 行った。その結果、本研究の範囲で次の知見が得られた。 （1）再生粗骨材コンクリートの圧縮強度

各種不純物を含む再生粗骨材を用いたコンクリートの 圧縮強度は、再生粗骨材の置換率 $30 \%$ およひ $50 \%$ の

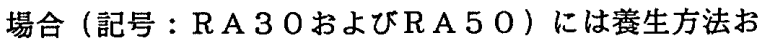
よび材齢によらず不純物を含まない再生粗骨材コンクリ 一ト（記号：N F 1 O O ) より大きいかまたは等しい。 しかし全量再生粗骨材を置換した再生コンクリートの場 合（記号：R A 100）は、養生方法および仕上材の種 䫓によって異なるが、低下する傾向を示した。特に、ア

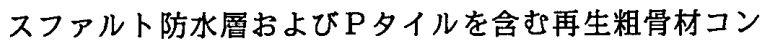
クリート（記号：A P 100 および P T 100 ）の圧縮 強度が小さい。

（2）再生粗骨材コンクリートの静弾性係数

各種不純物を含む再生粗骨材を用いたコンクリートの 静弾性係数は、再生粗骨材の置換率 $30 \%$ および $50 \%$ の場合には恙生方法および材秢によらず不純物を含まな い再生粗骨材コンクリートより大きい。しかし全量再生 粗骨材を置換した再生コンクリートの場合は、養生方法、 仕上材の種類および材齢によっては小さくなるものがあ

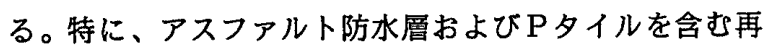
生粗骨材コンクリートの静弾性係数が小さい。また再生 粗骨材コンクリートの静弾性係数を実際に得られた圧縮 強度の值を使用して推定する際には、全量再生粗骨材を 使用したコンクリートの場合には気乾単位容積質量 $\gamma$ の 值の補正が必要であるが、材柃2 8 日に関しては、学会 規準式を、材歯 1 年に関してはAＣＩ規準式を用いて算 出することができる。

（３）再生粗骨材コンクリートの乾燥収縮

各種不純物を含む再生粗骨材を用いたコンクリートの 乾燥収縮は再生粗骨材の置換率 $30 \%$ および $50 \%$ の場 合には不純物を含まない再生粗骨材コンクリートより小 さい。しかしながら、全量再生粗骨材を置換した再生コ ンクリートの場合は大きくなる傾向を示した。特に、石 甭プラスターおよびPタイルを含む再生粗骨材コンクリ 一トの乾熉収縮が大きい。また再生粗骨材コンクリート の乾燥収縮は普通コンクリートに比べ長期間にわたるた めに 1 年間程度の測定が必要である。

\section{(4) ガラスおよび土の影響}

砕石コンクリートおよび不純物を含まない再生粗骨材 コンクリートにガラスおよび土が含まれると圧縮強度に 対する影㗽は少ないが、静弾性係数は低下し乾燥収縮は 大きくなる傾向を示した。特に、土が含まれるとその傾 向が顕著であった。

謝辞

本稿を執筆するにあたり日本大学・福地利夫名誉教授、 高野孝次講師、戸田建設技術研究所・中川宗男プロジェ クトマネージャー、建材試験センター・飛坂基夫上級専 門職からこ助言、こ指䓕を睗りました。また、実験に際 して、日本建設業経営協会中央技術研究所の方々およひ 建材試験センター中央試験所の方々に多大の協力を得ま した。ここに記して謝意を表します。

\section{参考文献}

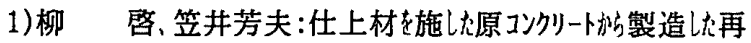
生粗骨材エンクリート諸物性(再生粗骨材コンクリート調合、凝結 から(プリーデイグ)，日本建築学会構造系論文集、No.464、 1994.10, pp. $7 \sim$ pp. 16

2) Yanagi.K,M.Hisaka and Y.Kasai:Physical properties of recycled concrete using recycled coarse aggregate made of concrete with finishing materials, Proceedings of the Third International Symposium RILEM, E \& FN SPON, pp. $379 \sim$ pp. 390,0 ct. 1993

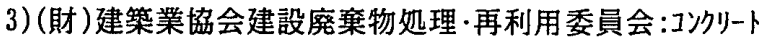
解体物0再利用闪関†研究, 昭 50.3

（1995年 2 月 10 日原稿受理，1995年 7 月13日採用決定） 